\title{
PLANKTON FERTILITY IN SUPPORTING FISH PRODUCTIVITY IN MONOTONOUS SWAMP IN HULU SUNGAI UTARA REGENCY
}

\author{
Slamat \\ Fishery Faculty of Lambung Mangkurat University. \\ Jl. Brigjen H. Hasan Basry Kalimantan Selatan (70714) \\ Email: slamat0106@gmail.com
}

\begin{abstract}
This study was carried out in a monotonous swamp in Hulu Sungai Utara Regency, South Kalimantan Province. The purpose was to find out the plankton fertility in supporting fish productivity in the monotonous swamp to build a dynamic waterbody with all of its supporting aspects. The analyses were performed on plankton diversity, water quality parameters and fish production levels from 2009 to 2013. The results of ShannonWiener diversity index analysis for plankton in the swamp approximately exceeded the value $(>2)$, indicating that the water condition was still good and fertile. The water quality parameters in the swamp were specific; blackish brown in color, acid, and having low level of oxygen with high ammonia concentration. The decreasing trends of fish productivity in the swamp were resulted from unselective fish catching, environmental pollutions and land-use changes converting the swamp areas into plantations and housing. Therefore, it is necessary to develop conservation areas to keep the primary productivity of the waterbody in high level, which would affect the increase in the productivity of swamp fish.
\end{abstract}

Keywords: plankton, water quality, fish productivity

\section{INTRODUCTION}

South Kalimantan province has various types of waterbodies, namely fresh, brackish and saline waterbodies, which are quite extensive. One type of fresh waterbodies located in Hulu Sungai Utara regency is swamp covering areas of \pm 301,260 ha. Various types of typical biota inhabiting the swamp have grown, and developed a mutual community. The increase and decrease in fish productivity are inseparable from the role of plankton as a source of nutrients in supporting growth and development of fish (Ji et al., 2010).
Plankton plays a very important role in a waterbody. Its ecological functions as the primary producer and the first link in a food chain make plankton often used as the fertility scale of a waterbody. The next stage is the transfer of energy from producers to higher trophic levels through a food chain (Suresh et al., 2009).

The role of plankton as the link between the primary producers and the large and small carnivores can affect the complexity of food chains in aquatic ecosystems. Plankton like other organisms can only live and thrive in suitable condition of waterbodies like seas, rivers, swamps and lakes (Ganai et al., 2010). Swamp ecosystem is a waterbody that can be influenced by inputs from several rivers carrying organic and inorganic materials. Around swamps are there some human activities that may alter the content of chemical compounds, the brightness and the discharge of water such as an increase in N, P, K contents, heavy metals and a decrease in the concentration of dissolved oxygen due to flourishing water plants covering most of the water surface.

Environmental changes that occur in a waterbody will affect the presence of plankton, either directly or indirectly. Community structure and distribution pattern of plankton in the waterbody can be used as biological indicators in determining the change in water conditions (Rodrigues et al., 2011). According to Atici et al. (2008) plankton diversity can be used as a biological indicator for water pollution. The environmental conditions of a polluted waterbody will affect the abundance of plankton which consequently affects the availability of nutrients for plankton-eating fish.

The productivity of fish in the monotonous swamp in Hulu Sungai Utara (HSU) Regency tends to experience a declining trend. One of the causes of the decrease in fish productivity is a decrease in plankton fertility due to the activities of people who live around the swamp and the 
pollution resulted from the coal wastes discharged into the swamp. The decrease in fish productivity has a major impact on the supply of animal proteins derived from fish because most people in South Kalimantan province like to consume swamp fish. Therefore, it is necessary to study plankton fertility in supporting the productivity of fish in the monotonous swamp to create a dynamic waterbody with all of its supporting aspects.

\section{MATERIALS AND METHODS}

The study was conducted in October 2013. There were several types of equipment needed for the study, such as planktonet, 25 $\mathrm{ml}$ sample bottle, bucket, measuring cup, object glass, cover glass, microscope, water quality measuring tools $(\mathrm{pH}$ meter, thermometer, sechi dish and bottles for water samples to analyze $\mathrm{DO}, \mathrm{CO} 2, \mathrm{NH} 3$ and TSS) and two guidebooks for identification written by Needham and Needham (1963), and Bolli et al. (1985). The material used in the study was $70 \%$ alcohol. The analyses of plankton and water quality were conducted at the Water Quality Laboratory of Fishery Faculty, Lambung Mangkurat University.

The process of plankton sampling was carried out in eight sampling locations by filtering as much as 50 liters of swamp water, putting them in a $25 \mathrm{ml}$ sample bottle and then adding $70 \%$ alcohol into the bottle. Plankton was identified by taking three drops of water sample and putting them in an object glass which then covered with a cover glass. There were 3 replications under a microscope at $100 \mathrm{x}$ magnification. The processes of identification and analysis were performed with the help of the guidebooks, as follows:

\section{A. Abundance of plankton}

$$
N=\frac{n}{m} x \frac{S}{a} x \frac{I}{v}
$$

Table 1. Phytoplankton abundance in a monotonous swamp in HSU Regency

\begin{tabular}{|c|c|c|c|c|c|c|c|c|}
\hline \multirow[b]{2}{*}{ Types of plankton } & \multicolumn{8}{|c|}{ Sampling Locations } \\
\hline & 1 & 2 & 3 & 4 & 5 & 6 & 7 & 8 \\
\hline Stigeoclonium chaetophora & 40 & - & - & - & 40 & 12 & 96 & 8 \\
\hline Richterella sp & 80 & - & - & - & - & - & - & - \\
\hline Ankistrodesmus selanastrum & 80 & - & - & - & - & - & - & - \\
\hline Protococus sp & 20 & - & - & - & - & - & - & - \\
\hline Sorestrum sp & 28 & - & 80 & - & - & - & 40 & - \\
\hline Coelosphaerium merismopedia & - & - & - & 4800 & - & - & - & - \\
\hline
\end{tabular}

Where:

$\mathrm{N}=$ Number of cells/l

$\mathrm{n}=$ Number of cells enumerated in $\mathrm{ml}$ hatching

$\mathrm{m}=$ Number of sample drops observed

$\mathrm{S}=$ Volume of sample with its preservation (ml)

$\mathrm{a}=$ Volume of each drop of sample (ml)

$v=$ Volume of the filtered water (liter)

B. Diversity index

Where:

$$
H=\sum_{i=1}^{s} n i / N(\log 2 n i / N)
$$

$\mathrm{H}=$ Diversity index

$\mathrm{s}=$ Number of species

$\mathrm{ni}=$ Number of individuals

$\mathrm{N}=$ Total number of individuals

C. Dominance Index

$$
C=\sum(n i / N)^{2}
$$

Where:

$\mathrm{C}=$ Dominance index

$\mathrm{ni}=$ the number of individuals at the i-th species in a sample

$\mathrm{N}=$ Total number of individuals in one station In situ analysis of water quality included $\mathrm{pH}$, temperature, odor, color and brightness while the laboratory analysis included DO, CO2, $\mathrm{NH} 3$ and TSS.

\section{RESULTS AND DISCUSSION}

Various types of plankton live in a swamp ecosystem. Plankton is regarded as one of the most important organisms in the world because it becomes food for aquatic life. In general, plankton can be divided into two types, phytoplankton and zooplankton. The results of the analyses of phytoplankton and zooplankton abundance in the monotonous swamp can be seen in Table 1 and 2. 


\begin{tabular}{|c|c|c|c|c|c|c|c|c|}
\hline Phormidium lynbya & - & - & - & 24 & - & - & - & - \\
\hline Aphanocapsa aphanothece & - & - & - & 2000 & - & - & - & - \\
\hline Diatoms & - & - & - & - & - & - & - & - \\
\hline Synedra sp & 40 & - & 24 & - & 244 & 8 & 52 & 44 \\
\hline Mastogloia cocconeis & 1548 & 28 & 164 & 648 & - & 236 & - & 276 \\
\hline Navicula achanthes & 16 & - & - & - & - & - & - & - \\
\hline Stauroneis sp & 20 & - & - & - & - & - & - & - \\
\hline Melocera sp & 28 & 400 & - & - & 84 & 8 & 16 & 120 \\
\hline Nitzchia sp & - & 16 & 16 & 32 & - & 12 & - & 60 \\
\hline Gomphonema rhoicosphenia & - & - & - & - & - & - & - & 8 \\
\hline Cyclotella stephanodiscus & - & - & - & - & 280 & - & - & 8 \\
\hline Diatoma sp & - & 400 & 128 & 56 & 204 & - & 44 & - \\
\hline Cymbella amphora & - & 4 & - & - & - & - & - & - \\
\hline Surella campylodiscus & - & 4 & - & - & - & - & - & - \\
\hline Desmids & - & - & - & - & - & - & - & - \\
\hline Penium closterium & 60 & - & - & 32 & 44 & 8 & 40 & - \\
\hline Desmidium gymnozyga & - & - & - & - & - & 80 & 40 & - \\
\hline Abundance (cells/liter) & 2388 & 860 & 412 & 7600 & 896 & 372 & 328 & 524 \\
\hline $\begin{array}{l}\text { Diversity Index (Shannon- } \\
\text { Wiener) }\end{array}$ & 1.8862 & 1.4299 & 1.9330 & 0.9650 & 2.2554 & 1.2126 & 2.2818 & 1.9086 \\
\hline Dominance index & 0.4523 & 0.4342 & 0.2976 & 0.0766 & 0.2368 & 0.4064 & 0.1609 & 0.3507 \\
\hline
\end{tabular}

Table 2. Zooplankton abundance in a monotonous swamp in HSU Regency

Types of plankton

Sampling Locations

\begin{tabular}{|c|c|c|c|c|c|c|c|c|}
\hline & 1 & 2 & 3 & 4 & 5 & 6 & 7 & 8 \\
\hline Protozoa & - & - & - & - & - & - & - & - \\
\hline Peridium sp & 533 & 27 & 89 & 933 & 236 & 13 & 31 & 129 \\
\hline Paranema sp & 400 & - & - & - & - & - & - & - \\
\hline Eudorina $s p$ & 67 & - & 44 & 44 & 44 & 44 & 444 & 400 \\
\hline Polytoma sp & - & - & - & - & - & - & - & 36 \\
\hline Pandorina $s p$ & - & - & 116 & 1116 & - & - & - & 142 \\
\hline Chlamydomonas sp & - & - & - & - & - & - & - & 22 \\
\hline Gonium sp & - & - & - & - & - & - & - & 5 \\
\hline Uroglena sp & - & - & - & - & - & - & 44 & - \\
\hline Trinema $s p$ & - & - & - & 18 & - & - & 62 & - \\
\hline Entosiphon sp & - & - & 89 & 449 & - & - & 40 & - \\
\hline Synora sp & - & - & 311 & - & 93 & 89 & - & - \\
\hline Genicularia sp & - & 444 & - & - & - & - & - & - \\
\hline Rotefera & - & - & - & - & - & - & - & - \\
\hline Keratella kellicottia & 44 & - & 44 & 44 & 22 & 9 & 18 & 22 \\
\hline Acyclus cupelopagis & 18 & 4 & - & 31 & - & - & - & - \\
\hline Macrochaetus ploesoma & 44 & - & 9 & - & - & 9 & - & - \\
\hline Filina hexartha & 13 & - & 9 & - & - & 4 & - & - \\
\hline Microcodon enteroplea & - & - & - & 13 & - & - & - & 22 \\
\hline Trichocerca scaridium & - & 4 & 4 & 13 & - & - & 22 & 27 \\
\hline Dicranophorus sp & - & - & - & 22 & 4 & - & - & 22 \\
\hline Chromogaster ascomorpha & - & - & 4 & - & - & - & - & 9 \\
\hline Epiphanes rhinoglena & - & - & 9 & 18 & 4 & 18 & - & 9 \\
\hline Mytilina trichotria & - & - & 9 & - & - & 9 & - & - \\
\hline Platias testudinella & - & 5 & - & - & - & 5 & - & - \\
\hline Philodina rotaria & - & - & - & - & - & 4 & - & - \\
\hline Hexartha polyartha & - & - & 4 & - & - & 9 & - & - \\
\hline Euclanis lepadella & - & 4 & 13 & 204 & - & - & - & - \\
\hline Ramate jaws & - & - & - & 22 & - & - & - & - \\
\hline Crustacea & - & - & - & - & - & - & - & - \\
\hline Cyclops sp & 9 & - & 9 & - & - & - & - & - \\
\hline Osphranticum limnocalanus & 13 & - & - & - & - & - & - & - \\
\hline Macrothrix sp & 18 & - & - & 13 & 44 & - & 22 & 9 \\
\hline Eubranchipus branchinella & 18 & 4 & 4 & 9 & - & - & - & - \\
\hline Nauplius sp & 44 & 27 & 13 & 116 & - & 13 & 22 & 22 \\
\hline Canhocamptus sp & 22 & 13 & - & 18 & - & - & - & - \\
\hline Bosmina sp & 22 & - & - & - & - & - & 18 & - \\
\hline Daphnia sp & 44 & - & 4 & 67 & - & - & - & - \\
\hline Simocephalus sp & 22 & - & - & - & - & - & - & - \\
\hline Ceriodaphnia moina & 22 & - & - & - & - & 9 & - & - \\
\hline
\end{tabular}




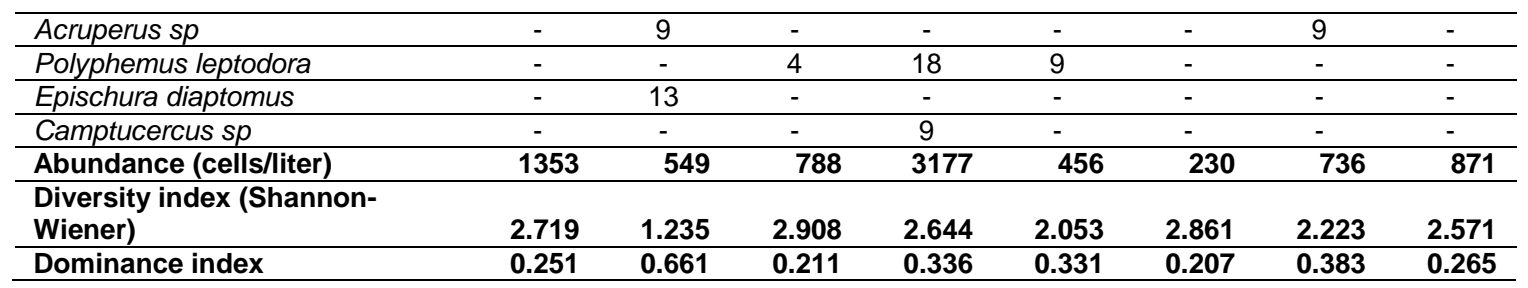

Sampling locations: 1. Sungai Malang, 2. Danau Selaba, 3. Pulau Tambak, 4. Sungai Rukam, 5. Danau Panggang, 6. Babirik, 7. Sungai Buluh, 8. Muara Tapus

It can be inferred from the results of the analysis that there were variations of abundance and diversity of plankton living in the waterbody. Plankton abundance can be used as the biological indicator in determining the levels of plankton fertility and aquatic environment damage due to contamination. The levels of contamination based on the abundance of plankton can be divided into several levels; uncontaminated (>2.0), light (1.6 - 2), moderate (of $1-1.5$ ), heavy $(<1.0)$ (Lee, 1978).

On the basis of the contamination levels by Lee (1976), the results of diversity index analysis of plankton in the monotonous swamp in Hulu Sungai Utara Regency indicated that the biological indicators illustrated the conditions of the aquatic environment (Table 1 and 2). The results of phytoplankton and zooplankton analyses in eight sampling locations can be described as follows:

The waterbody with the criteria of very fertile and uncontaminated with diversity index value of more than $2(>2)$ can be found in Danau Panggang and Sungai Buluh. The fertility of both aquatic areas was supported by the high organic matter resources, the quite good water quality (Table 3), and the water flow from Nagara River. The waterbody with the criteria of fertile and lightly contaminated (1.6 - 2) can be found in Sungai Malang, Pulau Tambak, and Muara Tapus. The three aquatic areas were areas of seasonal agriculture; hence during dry season the whole areas were utilized for rice cultivation but during rainy season the areas were flooded, which stopped the agricultural activities. Zooplankton species were more dominant in those aquatic areas than phytoplankton. The waterbody with the criteria of moderately contaminated $(1-1.5)$ can be found in Telaga Salaba, Sungai Rukam and Babirik. In those areas zooplankton species were also more dominant than phytoplankton. According to Badsi et al. (2010), the growth of phytoplankton will lower the growth of zooplankton because of the spatial pressure and the utilization of phytoplankton as the nutrients for zooplankton.

In general, the growth of plankton in the monotonous swamp was dominated more by the growth of zooplankton. The growth of phytoplankton occurred at the beginning of rainy season when the just inundated waterbody contained much organic matter as the nutrients, followed by the growth of zooplankton that utilized phytoplankton as its nutrients. According to Davies et al. (2006), there are several aspects that can affect the abundance and diversity of plankton, namely the water quality such as $\mathrm{DO}, \mathrm{CO} 2, \mathrm{NH} 3$, Salinity, $\mathrm{pH}$, temperature and heavy metals, the large number of plankton-eating fish, the high organic matter and the relatively shallow waterbody; therefore, plankton can be used as the biological indicator to figure out the contamination levels or the fertility of a waterbody. The great amount of plankton abundant in monotonous swamp will have a great impact on the growth and development of swamp fish that generally will spawn at the beginning of rainy season. The growth of fish fry in a waterbody will be inversely proportional to the growth of plankton because most of plankton will be consumed by fish fry as their initial nutrient (Sanyu and Schagerl, 2010). 
Table 3. Water quality at plankton-sampling locations in monotonous swamp

\begin{tabular}{|c|c|c|c|c|c|c|c|c|c|c|}
\hline \multirow[b]{2}{*}{ No } & \multirow[b]{2}{*}{ Parameter } & \multirow[b]{2}{*}{ Unit } & \multicolumn{8}{|c|}{ Sampling locations } \\
\hline & & & 1 & 2 & 3 & 4 & 5 & 6 & 7 & 8 \\
\hline 1 & Color & - & $\begin{array}{l}\text { Light } \\
\text { brown }\end{array}$ & $\begin{array}{c}\text { Blackish } \\
\text { brown }\end{array}$ & $\begin{array}{c}\text { Blackish } \\
\text { brown }\end{array}$ & Blackish & $\begin{array}{l}\text { Light } \\
\text { brown }\end{array}$ & $\begin{array}{c}\text { Light } \\
\text { brown }\end{array}$ & $\begin{array}{c}\text { Blackish } \\
\text { brown }\end{array}$ & $\begin{array}{c}\text { Blackish } \\
\text { brown }\end{array}$ \\
\hline 2 & Odor & - & Muddy & Rotten & Rotten & Rotten & Rotten & Muddy & Rotten & Rotten \\
\hline 3 & Brightness & $\mathrm{cm}$ & 20 & 25 & 30 & 30 & 30 & 30 & 35 & 30 \\
\hline 4 & Temperature & ${ }^{\circ} \mathrm{C}$ & 30 & 29 & 29 & 27 & 28 & 28 & 27 & 27 \\
\hline 5 & $\mathrm{pH}$ & - & 7.0 & 6.8 & 6.5 & 6.5 & 6.5 & 6.5 & 6.5 & 6.5 \\
\hline 6 & TSS & $\mathrm{mg} / \mathrm{tt}$ & 6.0 & 6.0 & 8.0 & 6.0 & 10.0 & 9.0 & 8.0 & 8.0 \\
\hline 7 & $\mathrm{DO}$ & $\mathrm{mg} / \mathrm{lt}$ & 4.8 & 4.1 & 4.0 & 4.0 & 3.2 & 3.0 & 3.1 & 3.2 \\
\hline 8 & $\mathrm{CO} 2$ & $\mathrm{mg} / \mathrm{lt}$ & 6.6 & 6.5 & 6.60 & 8.25 & 13.75 & 14.0 & 12 & 11.00 \\
\hline 9 & NH3 & $\mathrm{mg} / \mathrm{lt}$ & 0.15 & 0.23 & 0.25 & 0.15 & 0.25 & 0.26 & 0.16 & 0.15 \\
\hline
\end{tabular}

Plankton community structure in a water body is determined by environmental conditions and food availability like the availability of organic matter as the nutrients for the growth of plankton. When the environmental conditions are in accordance with the plankton need, the processes of maturization and fertilization for zooplankton and phytoplankton will occur, as well as the process of cell division for phytoplankton to multiply its cells. The water quality in the monotonous swamp is typical; blackish brown in color, acid, low level of oxygen, and quite high concentration of ammonia, so the types of biota that live in this waterbody tend to be adaptive to the environment. The results of water quality analysis at eight sampling stations in the monotonous swamp (Table 3) showed different variations. There were several factors influencing the flow of water, namely the composition process of organic materials such as grass and hay growing in dry season, the human activity of discharging the waste into the swamp, and the wastewater from coal mining that partly flowed into the swamp.

Areas far from the activity of disposing such toxic waste, such as Sungai Malang, Pulau Tambak, and Sungai Buluh were the areas for spawning fish. In the process of spawning, swamp fish tend to prefer shallow waterbodies having weak currents, many water plants, rather dark color and much plankton (Slamat et al, 2011). Naturally the mother fish would spawn at the start of rainy season when the color of the water is still a bit dark due to high dissolved organic matter. The dark water in a waterbody becomes a distinct advantage for fry fish that use it for shelter to avoid the attack of pests hiding in the grasses growing in the waterbody.

The growth of fish in the monotonous swamp was quite high, which can be seen from some aspects like genetic diversity of the fish that was higher than that of the fish in rain-fed and tidal swamps, quite high abundance of plankton, better water quality and large total areas of the swamps (Slamat et al, 2012).

Table 4. Productivity of fish in monotonous swamp in HSU Regency

\begin{tabular}{lllllll}
\hline \multirow{2}{*}{ No } & & & & & \\
& & $20 a r$ & & & \\
\cline { 3 - 6 } & Fish species & 2009 & 2010 & 2011 & 2012 & 2013 \\
\hline 1 & Betok (Anabas testudinius) & 7,001 & 6,408 & 6,055 & 5,896 & 3,170 \\
\hline 2 & Tambakan (Helostom. temencki) & 4,112 & 3,462 & 3,061 & 3,170 & 2,011 \\
\hline 3 & Sepat rawa (Trichogaster trichopterus) & 13,001 & 11,790 & 10,011 & 9,011 & 8,150 \\
\hline 4 & Sepat siam (Trichogaster pectorales) & 7,001 & 6,360 & 5,260 & 5,011 & 3,501 \\
\hline 5 & Nilem (Ostiocellus hasselti) & 8,122 & 7,041 & 6,240 & 5,571 & 4,806 \\
\hline 6 & Tawes (Puntius javanicus) & 8,110 & 7,490 & 6,302 & 6,811 & 5,146 \\
\hline 7 & Gabus (Canna striata) & 11,001 & 10,051 & 10,261 & 6,461 & 5,490 \\
\hline 8 & Tauman (Channa micropeltis) & 4,003 & 2,79 & 2,181 & 2,011 & 1,990 \\
\hline 9 & Baung (Hemibagrus nemurus) & 4,112 & 3,022 & 3,003 & 3,002 & 2,520 \\
\hline
\end{tabular}

Source: 2009 - 2012 DKP of South Kalimantan Province, and a field survey in 2013

Fish is one of heterotrophic organisms; in this case fish is the secondary productivity in a waterbody. The number of secondary productivity of a community depends on the 
number of primary productivity in the community. The abundance of fish in one place cannot be separated from the sources of nutrients available, such as plankton. The abundance of plankton in a waterbody has a positive impact on the organisms positioned higher than plankton in the structure of a food chain.

The migration of fish to spawning areas is for adjustment and reassurance to the most favorable place for development of eggs and larvae (Angelini et al, 2006). Similarly, the migratory fish from rivers to swamps aim at getting a specific place that is safe and provides nutritional and ecological needs for the development of eggs and larvae with the adequate availability of plankton.

The fertility of a waterbody can be seen from the presence of plankton organisms because plankton can describe the productivity level of the waterbody. In the trophic system of aquatic ecosystem, including the peat swamp ecosystem, plankton plays an important role as a producer and is placed on the ground level. Therefore, the presence of plankton in a waterbody affects the survival of fish, especially the plankton-eating fish or fish that are in the early development stage.

The productivity of fish in the monotonous swamp tends to decrease from year to year, especially in 2013, which can be seen from the data taken from the field survey (Table 4). A decrease in productivity is due to several factors, such as unselective fishing like capturing the fish fry and the parent fish in large numbers, the environmental pollution such as household waste and coal waste causing a decrease in primary producers, and the conversion of swamp areas into plantations and housing. The greatest impact of the pollution on a waterbody is the declining of primary productivity such as plankton. Some efforts to maintain the fertility of plankton to increase the productivity of fish can be carried out, such as developing a reservation as a protected conservation area, controlling selected fishing by all fishermen, keeping the aquatic environment clean, prohibiting the use of hazardous materials and tools for catching fish, and conducting restocking activities to keep the balance of fish populations in the reservation area.

\section{CONCLUSIONS}

Plankton is a primary producer whose role is very important in supporting aquatic productivity. The analysis results of the Shannon-Wiener diversity index of phytoplankton and zooplankton in the monotonous swamp exceeded the average value $(>2)$ which shows that the condition of the swamp was still good and fertile. The water quality in the swamp was relatively typical of blackish brown, acid, having low oxygen level and high ammonia concentration. The decrease in fish productivity in the swamp shows a decreasing trend caused by unselective fishing, the environmental pollution, and the conversion of swamp lands into plantations and housing; therefore it requires reservation area to keep the primary productivity remain high, which has an implication on the increase in the productivity of swamp fish in general.

\section{REFERENCES}

Angelini, R., N.F. Nídia and L.S.J.R. Urbano. 2006. Trophic analysis and fishing simulation of the biggest amazonian catfish. African Journal of Agricultural Research. 1 (5): 151158.

Anonim. 2010. Annual Report of Marine and Fisheries Agency, South Kalimantan Province. DKP KalSel.I

Atici, T., A. Seyhan., A. Ahmet and A. Didem. 2008. Ecological effects of some heavy metals $(\mathrm{Cd}, \mathrm{Pb}, \mathrm{Hg}$, $\mathrm{Cr})$ pollution of phytoplanktonic algae and zooplanktonic organisms in sarıyar dam reservoir in Turkey. African Journal of Biotechnology. 7 (12): 1972-1977.I

Badsi, H., H.O. Ali., M. Loudiki., M. El Hafa., R. Chakli and A. Aamiri. 2010. Ecological factors affecting the distribution of zooplankton community in the Massa Lagoon (Southern Morocco). African Journal of Environmental Science and Technology. 4(11): 751-762.

Bolli, M.H., B.S. John., P.N. Katharina, 1985. Plankton stratigrphy. Cambridge University Press. pp 106.

Davies, O.A., Alfred., J.F. Ockiya and A. Asele. 2006. Induced growth of phytoplankton using two fertilizers (NPK and agrolyser) under laboratory conditions. African 
Journal of Biotechnology. 5 (4): 373-377.

Ganai, H.A., P. Saltanat., A.K. Asif and H. Maryam. 2010. Phytoplankton diversity at watlab ghat in wular lake, Kashmir. Journal of ecology and the natural environment. 2(8): 140-146.

Ji, R., Martin., L.M. David., A.R. Jeffrey and C.T. Andrew. 2010. Marine plankton phenology and life history in a changing climate: Current research and future directions. Journal of plankton research. 32(10): 1355-1368.

Lee, T.D. 1978. Handbook of variables of environmental impact assessment. Arbor: An arbor science publisher inc.

Needham, J.G and R.P. Needham. 1963. A guide to study of freshwater biology. Holden day inc, San Fransisco. pp. 1248.

Rodrigues, R.H.L., B.C. Eliete., B. Vanessa., G. Vanessa., H. Ângela and M.M. David. 2011. Dynamics of plankton and fish in a subtropical temporary wetland: Rice fields.
Journal Scientific Research and Essays. 6(10): 2069-2077.

Sanyu, A.G and S. Michael. 2010. Phytoplankton productivity in newly dug fish ponds within Lake Victoria wetlands (Uganda). African Journal of Environmental Science and Technology. 4(5): 30-40.

Slamat., M.T. Ahmad and T.S. Dinar. 2011. Genetic Diversity of betok fish (Anabas testudineus) at three ecosystems of swamp waterbody in South Kalimantan: Journal of Agrocientiae :18. 129 - 135.

Slamat., Marsoedi., M. Athaillah and A. Diana. 2012. Genetic Conservation of betok fish (Anabas testudineus Bloch 1792) at swamp waterbody in South Kalimantan. Research Journal of Indonesian Fishery: 18. 9-15.

Suresh, B.S., Manjappa and T.E. Puttaiah. 2009. The contents of zooplankton of the tungabhadra river, near harihar, karanataka and the saprobiological analysis of water quality. Journal of ecology and the natural environment 1(9): 196-200. 